\title{
Promoting Sustainable Economic Growth in South Africa THROUGH THE EXPORT OF LOW-CARBON ENVIRONMENTAL GOODS
}

\author{
Antoinette van Niekerk and Wilma Viviers
}

School of Economics and TRADE Research Entity,

North-West University, Potchefstroom Campus

Accepted: March 2014

\begin{abstract}
Many countries, particularly those in the developing world, are under increasing pressure to improve their growth rates in order to tackle pressing economic problems at the domestic level. Increasing export volumes can make a positive contribution to a country's economic growth rate, but it can also endanger the environment. How to reconcile the often conflicting phenomena of increased export activity, stronger economic growth and a lower carbon footprint is the focus of this study.

A core outcome of the study was the creation of a single list using a cross-section of international sources, of low-carbon environmental goods, and their ranking according to their inherent ability to reduce greenhouse gas emissions, South Africa's capacity to produce them, and their economic benefits, as reflected in the export opportunities they present. These export opportunities were revealed through the application of the Decision Support Model (DSM), an export market selection tool that incorporates a systematic filtering and screening system.

The results of the analysis should help guide policymakers in their strategic deliberations on which export sectors to incentivise and support with a view to encouraging more 'green' growth in South Africa in the years ahead.
\end{abstract}

Key words: economic growth, exports, green growth, greenhouse gas emissions, low-carbon technologies, low-carbon environmental goods

JEL: F18, Q42, 56

1

\section{Introduction}

Economic and environmental objectives are traditionally seen as contradictory, as continued economic growth puts increasing pressure on certain biophysical limits that produce symptoms like extinction, resource shortages and climate change (Czech, 2000:177). Consequently, it is difficult to enforce policies that simultaneously encourage stronger economic growth on the one hand and decrease in greenhouse gas emissions on the other.

Export promotion and foreign market development are usually seen as stimulants to economic growth, which, in South Africa's case, is recognised as an important element in the fight against poverty, inequality and unemployment. Yet greater export volumes often endanger the environment. If a country's economic wellbeing is enhanced by an increase in exports, a strategy should be formulated that ensures that higher export volumes also have, in some way, positive consequences for the environment.

An increase in exports has a range of positive consequences. It stimulates the circular income-spending-production flow of an economy (Mohr \& Fourie, 2008:51), thereby generating higher levels of foreign exchange for a country. Furthermore, increased exports have a positive effect on the balance of payments (Mmieh, Owusu-Frimpong \& Mordi, 2012; Aitken, Hanson \& Harrison, 1997). In addition, a study by Naudé, Bosker and Matthee (2010), using data from 1996 to 2001, found that a region that was more open to trade had higher levels of local economic development, a bettereducated population and higher GDP growth. Increased exports also promote economic growth when they are accompanied by greater worker productivity (Abor, 2010:9), and can improve a firm's technological base and competitive advantage (Mmieh et al., 2012). 
For example, a 10 per cent increase in South Africa's openness to trade from 1990 to 1998 led to a 5 per cent increase in long-run total factor productivity gains (Jonsson \& Subramanian, 2001). Not surprisingly, South Africa's National Development Plan identifies increased exports as a key driver of higher economic growth rates (National Planning Commission, 2011).

South Africa has seen many ups and downs in its economic growth performance over the years. In the decade before the first democratic elections, sanctions on trade and capital flows, together with political turmoil, contributed to weak economic growth in the country. After 1994, economic growth trends began to improve, helped by a more liberal trade regime, which included the elimination of various trade barriers (Du Plessis \& Smit, 2007). However, in recent years, the global financial crisis and changing global alliances and market requirements have made the business of exporting from South Africa more challenging, which has taken its toll on economic growth. Clearly, export promotion has to be taken to a new level if the country is to meet its growth and development goals. However, an increase in exports is usually accompanied by higher levels of greenhouse gas emissions. This runs contrary to the idea of responsible growth.

'Green' growth is a relatively new term, and is associated with an economy whose growth strategy incorporates environmental, economic and social objectives (Low, 2011:1). Environmental objectives would include lowering greenhouse gas intensity, maintaining biodiversity and the integrity of ecosystem services, and increasing climate change resilience. Economic objectives would include increasing the economic growth rate and boosting capacity in less productive areas. Finally, social objectives would include raising the level of human development and reducing poverty. These environmental, economic and social objectives are shown as the medium grey segments in Figure 1, while green growth is depicted as the dark star in the centre. The light grey segments each represent the intersection between two of the broader environmental, economic and social objects.

Figure 1

Various components of a green economy

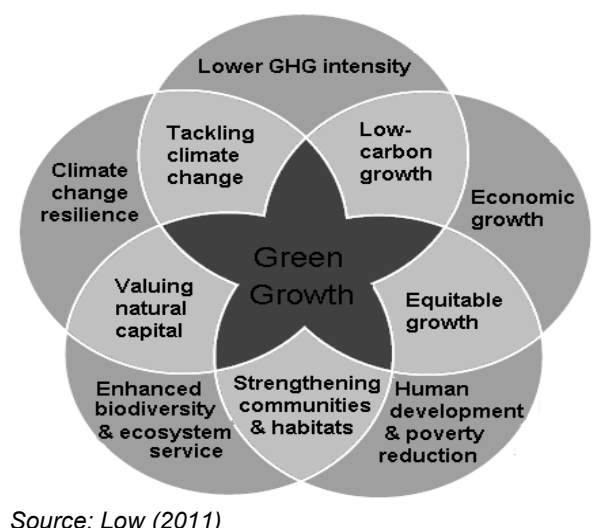

This study will focus on low-carbon growth, which is an important element in the green growth mix. In Figure 1, low-carbon growth is shown as the intersection (light grey area) between economic growth and lower greenhouse gas intensity.

Lower greenhouse gas emission is important to ensure a healthy environment. A healthy environment offers various benefits to an

economy in terms of the goods and services it provides. The most fundamental of these environmental services is the biophysical environment that resides within the limits of organic life (Tietenberg \& Lewis, 2009). One of the most critical of the biophysical variables that maintain these limits is a very narrow range in ambient temperatures. This temperature range is created by an atmospheric greenhouse 
effect that maintains global temperatures at an average of $14^{\circ} \mathrm{C}$ (World Meteorological Organization, n.d.). The composition of atmospheric gases should therefore be sustained, as any alterations could shift global temperatures to outside the optimal range for organic life forms.

South Africa is a carbon-intensive economy, which means that the amount of greenhouse gas emitted for economic output is high (Davidson, Winkler, Kenny, Prasad, Nkomo, Sparks, Howells \& Alfstad, 2006:4). The carbon intensity of an economy can be reduced by consuming more low-carbon environmental goods. Therefore, if low-carbon environmental goods are commonly used in South Africa, this could potentially decrease the carbon intensity of the economy. This argument is not as straightforward as it might appear, however, as some low-carbon goods can produce negative environmental effects at the production stage, such as the release of fluoride pollution during the production of solar panels. There can also be undesirable secondary effects when lowcarbon goods are used, such as birds being killed by the blades of wind turbines. In view of such complexities, this study will consider the effects of low-carbon goods only when they are consumed as intended, e.g. generating electricity from wind turbines, and not the potential negative implications for the environment when the goods are produced or unintended effects in consumption.

There is a clear connection between a strong export culture and positive economic growth trends. Thus, promoting the export of lowcarbon environmental goods with particularly high export potential could eventually lead to higher economic growth in South Africa, with lower greenhouse gas intensity. Against this background, the aims of this study are:

- to explain the relationship between greenhouse gases and increased export activity;

- to create a list of low-carbon environmental goods and identify which of these have the greatest potential for reducing greenhouse gases and encouraging economic growth in South Africa; and

- to explore the economic benefits of the best low-carbon environmental goods, including the intensive and extensive export opportunities associated with them.

\section{2}

\section{Literature review}

Clearly, policymakers in South Africa should aim to boost economic growth through a more focused export promotion effort that would also be gentler on the environment. The following literature review examines what various authorities and other entities say about the interrelationships among enhanced export levels, the environment and economic growth, and the key role that low-carbon environmental goods can play in an economy.

\subsection{The relationship between the environment and increased export activity}

A study by the World Trade Organization (WTO) and the United Nations Environmental Program (UNEP) identified three effects of liberalised trade on greenhouse gas emissions: the scale effect, the composition effect and the technique effect (Tamiotti, The, Kulaçoğlu, Olhoff,, Simmons \& Abaza, 2009).

The scale effect shows the degree to which greenhouse gases may increase as a result of greater economic activity (Tamiotti et al., 2009). If South Africa were to maintain its current level of carbon intensity, the scale effect would reveal an increase in greenhouse gas emissions due to heightened economic (industrial) activity. Another dimension of the scale effect would be that increased transportation across borders would similarly increase greenhouse gas emissions (Tamiotti et al., 2009).

The composition effect shows the degree to which the liberalisation of trade would change the relative prices of goods and services produced by certain sectors, which in turn could affect the relative size of those sectors and the composition of total production (Tamiotti et al., 2009). If less carbonated sectors expanded and replaced carbon-intensive sectors, greenhouse gas emissions would decline (Tamiotti et al., 2009).

Lastly, the technique effect shows the degree to which the adoption of superior lowcarbon technologies could potentially reduce the carbon intensity of the economy, at either the production or the consumption stage. As indicated earlier, this study will investigate only those goods that have a positive 
environmental impact at the consumption level.

The WTO's Doha Ministerial Mandate aimed to improve the global environment through the technique effect by encouraging the free trade of environmental goods (Tamiotti et al., 2009). However, the net effect of trade liberalisation on greenhouse gas emissions is difficult to quantify. While the scale effect points to an increase in emissions, the composition effect points to a decrease. Thus, the two effects work in opposite ways. Whether the technique effect reflects a rise or fall in greenhouse gas emissions depends on the products traded and the countries involved. In this study, the spotlight is on low-carbon environmental goods shipped from/to South Africa. Given that South Africa is a greenhouse gas-intensive country and low-carbon environmental goods, by definition, decrease greenhouse gas emissions, the use of the technique effect in this study will reveal a potential reduction in emissions. Through a combination of the three effects, an increase in exports of low-carbon environmental goods could have a positive environmental outcome for South Africa. The liberalisation of lowcarbon environmental goods would therefore enable them to circulate more freely in the country, which would help to decrease the carbon intensity of the economy.

\subsection{Diffusion of low-carbon technologies}

The impact of the technique effect depends on how well goods are accepted into the country. The acceptance of new technologies by a community is called the diffusion of technologies into that community. This diffusion does not occur instantaneously, but follows an Sshaped curve over time, known as a sigmoid curve (Löschel, 2002:106). Technologies can be diffused through various channels, such as foreign direct investment, imitation, knowledge spill-overs, the migration of skilled labour, or international trade (Groizard, 2007:2). Of all the channels, trade consistently proves to be one of the most important (Groizard, 2007:2), with increased trade having the potential to significantly accelerate the rate of diffusion. In this regard, the removal of trade barriers since 1994 has increased the rate at which technologies have been diffused into developing countries by about 80 per cent (Mundial, 2008).

It follows that trade liberalisation has a key role to play in diffusing low-carbon technologies into developing countries or carbonintensive economies (Panitchpakdi, 2011). Importantly, too, the spread of environmental goods into an economy is accompanied by the sharing of knowledge and environmental best practices, and general cooperation between the countries concerned.

A study by the International Energy Agency (IEA) concluded that existing low-carbon technologies could substantially reduce global carbon levels (IEA, 2008). Thus, liberalising the trade in low-carbon environmental goods could increase the rate of diffusion of lowcarbon technologies, which has the potential to reduce the greenhouse gas intensity of the South African economy. Furthermore, if the export of these goods was encouraged, South Africa's economic growth rate could rise. However, given the country's uneven economic capacity and potential, selective industry protection would undoubtedly be needed to steer such a reorientation.

\subsection{Deriving a list of low-carbon environmental goods}

According to Steenblik (2005:1), environmental goods and services (EGS) can be defined as those goods and services that measure, prevent, limit, minimise or correct environmental damage vis-à-vis various environmental entities. On the other hand, low-carbon environmental goods are defined as those goods that emit minimal or zero greenhouse gases during end use (Solarpowernotes, n.d.). The possible adverse effects associated with the production of these goods are not considered in this study.

Low-carbon environmental goods are only one type of environmental good. In order to create a list of low-carbon environmental goods, it is necessary first to make a list of all environmental goods and then isolate the lowcarbon environmental ones. Despite the Doha Ministerial Mandate calling for the elimination of tariffs on environmental goods, there is no official, universal list of environmental goods. Four existing lists of environmental goods classified according to their HS-6 codes for 
ease of comparison - are used in this study. They are from the World Trade Organization (WTO), the World Bank (WB), the International Centre for Trade and Sustainable Development (ICTSD) and the Fondation pour les Etudes et Recherches sur le Développement International (FERDI). In order to distil the low-carbon goods from the environmental goods, the research findings of the International Institute for Sustainable Development (IISD) were consulted (Wooders, 2009).

\subsubsection{The World Trade Organization (WTO) list}

This list was produced by the Friends of the EGS Group, who submitted an informal document listing 153 environmental goods, arranged in 12 sub-groups, to the WTO's Committee on Trade and Environment Special Session (CTESS, 2007). The list can be accessed at: http://www.mfat.govt.nz/downloads/NZ-WTO/ wto-dohaministerialdeclaration27apr07.pdf.

The IISD classified only goods in the Renewable Energy Plant sub-group as having a high potential to reduce greenhouse gas emissions (Wooders, 2009). As a result, only this sub-group, which contains 30 of the 153 environmental goods, has been included in the study.

\subsubsection{The World Bank (WB) list}

It was considered particularly important to include this list in the study, as the World Bank is a key role-player in debates about environmental goods. The list contains 13 environmental goods, which are divided into four sub-groups: a) clean coal technologies; b) wind energy; c) solar photovoltaic system; and d) energy efficient lighting (Wooders, 2009).

10 of the 13 goods overlap with those in the WTO list. Nine of these 10 are in the subgroup Renewable Energy Plant, and are already identified as low-carbon environmental goods. The remaining four goods were not included in the study, because the IISD concluded that they did not have sufficiently high potential to reduce greenhouse gas emissions (Wooders, 2009).

\subsubsection{The International Centre for Trade and Sustainable Development (ICTSD) list}

This list, which was compiled by Laborde and Lakatos in 2012 and submitted by the ICTSD, is the most recent. The ICTSD categorises environmental goods in three sub-groups: a) renewable products and energy sources; b) environmental monitoring, analysis and assessment equipment; and c) waste management, recycling and remediation.

Of the 63 environmental goods appearing in the ICTSD list, 50 overlap with those in the WTO list. Of these, 26 goods are in the subgroup Renewable Energy Plant, and are therefore already included in the final list of low-carbon environmental goods. The other 24 products were not included in the study because they were viewed by the IISD as having low, negligible or no potential to reduce greenhouse gas emissions (Wooders, 2009). Of the 13 goods named by the ICTSD but not included on the WTO list, nine are listed as renewable products and energy sources by the ICTSD and so they are included in the final list with the exception of 'fluorescent, hot cathode lamps' (HS-6: 853931) which are not specified as renewable energy but rather as a lighting source which has a limited potential to reduce greenhouse gas emissions.

\subsubsection{The Fondation pour les Etudes et Recherches sur le Développement International (FERDI) list}

This list is the result of a joint effort by representatives of Australia, Colombia, Hong Kong, China, Norway and Singapore to arrive at a core of 26 goods from the original 411 codes. It was considered important to include this list in the study because it is a good example of multinational collaboration (Balineau \& De Melo, 2011).

From the core list of 26 goods, 23 goods overlap with those in the WTO list, of which 13 goods are categorised in the Renewable Energy Plant sub-group and are therefore already included in the final list. The remaining 13 goods were dropped from further consideration because the IISD concluded that they did not have sufficient potential to reduce greenhouse gas emissions (Wooders, 2009).

\subsubsection{Final list of low-carbon environmental goods}

A final list of low-carbon environmental goods was derived (see Table 1) by working through 
the steps outlined in sections 2.3.1 to 2.3.4. In the table, the second column gives the HS-6 code for each product, and the third column gives a short description of the product as defined by the United Nations Commodity Trade Database (UN COMTRADE, 2010), while the last column indicates what the product is used for.

Table 1

Derived list of low-carbon environmental goods

\begin{tabular}{|c|c|c|c|}
\hline & HS -6 code & Product description & Used for \\
\hline 1 & 730820 & Towers and lattice masts & Used to elevate the blades of wind turbines. \\
\hline 2 & 761100 & $\begin{array}{l}\text { Aluminium reservoirs, vats, tanks, etc., } \\
\text { volume }>300 \text { l }\end{array}$ & $\begin{array}{l}\text { Used in the production of biogas and solar thermal } \\
\text { energy. }\end{array}$ \\
\hline 3 & 840681 & Turbines NES, of o $<40 \mathrm{mw}$ & $\begin{array}{l}\text { Designed for geothermal energy generation and co- } \\
\text { generation, which is more effective than conventional } \\
\text { methods. }\end{array}$ \\
\hline 4 & 840682 & Turbines NES, of o $>40 \mathrm{mw}$ & $\begin{array}{l}\text { Derive electrical power from environmental recovery } \\
\text { operations. }\end{array}$ \\
\hline 5 & 840690 & Parts of steam and vapour turbines & Used in maintenances of energy recovery turbines. \\
\hline 6 & 841011 & $\begin{array}{l}\text { Hydraulic turbines, water wheels, power } \\
<1000 \mathrm{~kW}\end{array}$ & Generate hydroelectric power. \\
\hline 7 & 841012 & Hydraulic turbines, small (1-10MW) & Generate hydroelectric power. \\
\hline 8 & 841090 & $\begin{array}{l}\text { Parts of hydraulic turbines and water } \\
\text { wheels }\end{array}$ & Generate hydroelectric power. \\
\hline 9 & 841181 & $\begin{array}{l}\text { Gas turbine engines NES of a power < } \\
5000 \mathrm{~kW}\end{array}$ & $\begin{array}{l}\text { Generate electrical power from recovered landfill gas or } \\
\text { biogas. }\end{array}$ \\
\hline 10 & 841182 & $\begin{array}{l}\text { Gas turbine engines NES of a power > } \\
5000 \mathrm{~kW}\end{array}$ & $\begin{array}{l}\text { Generate electrical power from recovered landfill gas or } \\
\text { biogas. }\end{array}$ \\
\hline 11 & 841221 & $\begin{array}{l}\text { Hydraulic power engines and motors, } \\
\text { cylinders }\end{array}$ & Generate hydroelectric power. \\
\hline 12 & 841229 & $\begin{array}{l}\text { Hydraulic power engines and motors, } \\
\text { others }\end{array}$ & Generate hydroelectric power. \\
\hline 13 & 841581 & $\begin{array}{l}\text { Air conditioners NES with reverse cycle } \\
\text { refrigeration }\end{array}$ & $\begin{array}{l}\text { Transfer the heat available in land and water masses to } \\
\text { either heat or cool buildings. }\end{array}$ \\
\hline 14 & 841861 & $\begin{array}{l}\text { Compression refrigeration equipment } \\
\text { with heat exchange condensers and } \\
\text { heat exchangers }\end{array}$ & $\begin{array}{l}\text { Transfers the heat available in land and water masses to } \\
\text { either heat or cool buildings. }\end{array}$ \\
\hline 15 & 841869 & Refrigerating or freezing equipment NES & $\begin{array}{l}\text { Transfers the heat available in land and water masses to } \\
\text { either heat or cool buildings. }\end{array}$ \\
\hline 16 & 841919 & $\begin{array}{l}\text { Instantaneous/storage water heaters, } \\
\text { not electric NES }\end{array}$ & Heat water through solar thermal energy. \\
\hline 17 & 841990 & $\begin{array}{l}\text { Parts, laboratory/industrial } \\
\text { heating/cooling machinery }\end{array}$ & Used in maintenances of solar water heaters. \\
\hline 18 & 848340 & Gearing and screws & $\begin{array}{l}\text { Convert slow rotation of blades of wind turbines to a } \\
\text { sufficient speed to generate electricity. }\end{array}$ \\
\hline 19 & 848360 & $\begin{array}{l}\text { Clutches, shaft couplings, universal } \\
\text { joints }\end{array}$ & Used in the maintenance and assembly of wind turbines. \\
\hline 20 & 850161 & AC generators, of an output $<75 \mathrm{kVA}$ & $\begin{array}{l}\text { Used in conjunction with boilers and turbines to produce } \\
\text { energy from renewable energy sources, such as biomass. }\end{array}$ \\
\hline 21 & 850162 & AC generators of an output $75-375 \mathrm{kVA}$ & $\begin{array}{l}\text { Used in conjunction with boilers and turbines to produce } \\
\text { energy from renewable energy sources, such as biomass. }\end{array}$ \\
\hline 22 & 850163 & AC generators $375-750 \mathrm{kVA}$ & $\begin{array}{l}\text { Used in conjunction with boilers and turbines to produce } \\
\text { energy from renewable energy sources, such as biomass. }\end{array}$ \\
\hline 23 & 850164 & AC generators of an output $>750$ kVA & $\begin{array}{l}\text { Used in conjunction with boilers and turbines to produce } \\
\text { energy from renewable energy sources, such as biomass. }\end{array}$ \\
\hline 24 & 850231 & Wind-powered electricity sets & Generate electricity from wind. \\
\hline 25 & 850239 & Electric generating sets & $\begin{array}{l}\text { Used to minimise the loss of (domestic) energy } \\
\text { transmission in the national grids. }\end{array}$ \\
\hline
\end{tabular}




\begin{tabular}{|c|c|c|c|}
\hline & HS- 6 code & Product description & Used for \\
\hline 26 & 850300 & Parts for electric motors and generators & $\begin{array}{l}\text { Are components of the nacelles and blades in wind } \\
\text { turbines used to generate electricity. }\end{array}$ \\
\hline 27 & 850440 & Static converters & Convert solar energy into electricity. \\
\hline 28 & 850610 & $\begin{array}{l}\text { Primary cells and batteries (manganese } \\
\text { dioxide) }\end{array}$ & Store renewable energy. \\
\hline 29 & 850630 & $\begin{array}{l}\text { Primary cells and batteries (mercuric } \\
\text { oxide) }\end{array}$ & Store renewable energy. \\
\hline 30 & 850640 & $\begin{array}{l}\text { Primary cells and batteries (silver } \\
\text { dioxide) }\end{array}$ & Store renewable energy. \\
\hline 31 & 850650 & Primary cells and batteries (lithium) & Store renewable energy. \\
\hline 32 & 850660 & Primary cells and batteries (Aird zinc) & Store renewable energy. \\
\hline 33 & 850690 & Primary cells and batteries, parts & Store renewable energy. \\
\hline 34 & 850720 & $\begin{array}{l}\text { Lead-acid electric accumulators except } \\
\text { for vehicles }\end{array}$ & Provide energy storage in off-grid photovoltaic systems. \\
\hline 35 & 853710 & $\begin{array}{l}\text { Electrical control and distribution boards, } \\
<1 \mathrm{kV}\end{array}$ & Control the functioning of the photovoltaic system. \\
\hline 36 & 854140 & $\begin{array}{l}\text { Photosensitive/photovoltaic/LED } \\
\text { semiconductor devices }\end{array}$ & Generate electricity from solar power. \\
\hline 37 & 900190 & $\begin{array}{l}\text { Prisms, mirrors and optical elements } \\
\text { NES, unmounted }\end{array}$ & Used to intensify and concentrate solar power. \\
\hline 38 & 900290 & $\begin{array}{l}\text { Mounted lenses, prisms, mirrors, optical } \\
\text { elements NES }\end{array}$ & Used to intensify and concentrate solar power. \\
\hline 39 & 903289 & $\begin{array}{l}\text { Automatic regulating/controlling } \\
\text { equipment NES }\end{array}$ & Control the processes in generating renewable energy. \\
\hline
\end{tabular}

Source: Compiled by the author with CTESS (2007)

\section{3}

\section{Empirical analysis}

The empirical analysis was conducted with two main objectives in mind: to rank the identified low-carbon environmental goods, and to identify intensive and extensive opportunities for the top-ranking goods.

The intensive margin is defined in the World Bank's Trade Diagnostic Toolkit as the increase in existing product-country export opportunities (Reis \& Farole, 2012:5). The extensive margin, in turn, is defined as a new product-country combination resulting from producing and exporting a 'new' product or exporting an existing product to 'new' markets (Reis \& Farole, 2012:5). For the majority of countries, particularly those in the middle to high-income categories, most export growth takes place in the intensive margin. This is true of South Africa as well. To reduce their vulnerability to external shocks, countries need to expand their exports in the extensive margin - by both creating new trade flows through new product innovation and selling existing products in new markets. Yet new export initiatives are fraught with challenges, and many falter within a short period (Viviers,
Cuyvers, Matthee, Steenkamp, Grater \& Krugell, 2013).

In view of the many hurdles South African producers face in getting new products off the drawing board and into production, the focus of this analysis was on identifying low-carbon environmental goods already being produced in South Africa and prioritising them in terms of their export potential in existing and new markets.

\subsection{Ranking the identified low-carbon environmental goods}

The 39 products classified as low-carbon environmental goods depending on their end use (see Table 1) are not identical in terms of their ability to reduce greenhouse gas emissions or stimulate economic growth. Nor are they equal in terms of South Africa's current capacity to produce them. The goods needed to be further classified according to three criteria: i) the ability to reduce greenhouse gas emissions; ii) South Africa's capacity to produce the goods; and iii) the potential economic benefits to be derived from exporting the goods. This process facilitated the final ranking of the goods. 


\subsubsection{Criterion 1: Ability of the good to reduce greenhouse gas emissions}

This criterion is based on the consensus of the different role players (the WTO, the WB, the ICTSD and the FERDI). A score of 1 was given to a product that each role player has identified as being a low-carbon environmental good. Thus, a maximum score of 5 was assigned to a product that appeared in all four lists and was also judged by the IISD as having a high potential to reduce greenhouse gas emissions. This total score was the first of three used to rank the low-carbon environmental goods.

\subsubsection{Criterion 2: South Africa's capacity to produce the good}

It was important to take South Africa's capacity to produce the goods into consideration, particularly as the country's production capacity in respect of the 39 low-carbon environmental goods varies. To measure South Africa's production capacity in respect of existing products, the Revealed Comparative Advantage $^{1}$ (RCA) was used.

The RCA measures whether a certain country exports proportionately more of a specific product in relation to its total exports than all other countries do, relative to their total exports (Huberty \& Zachmann, 2011). The RCA of the identified environmental goods differed substantially, although the average RCA could be used to detect the current relative advantage that South Africa has over other countries in exporting a specific product.

The average RCA was determined over a five-year period from 2006 to 2010 in order to lessen the effect of possible outliers, and International Trade Centre data (ITC, 2011) were used. For this exercise, a score out of 5 for each of the final low-carbon environmental goods that South Africa currently produces was derived from the RCA of the different products. This RCA serves as a proxy for South Africa's production capacity in respect of such products.

\subsubsection{Criterion 3: Potential economic benefits to be derived from exporting the good}

The third and last criterion looked at the economic benefits that could potentially result from exporting each low-carbon environmental good. In measuring the benefits of increased exports of such products, only the potential export value was taken into account. Other benefits, such as an increase in consumer demand, government spending and investment, were not considered. Thus, potential export value can serve as a proxy for potential economic benefits.

In order to calculate the potential export value of a specific good, the market share and growth, and the number of countries that present export opportunities for the product were taken into consideration. Steenkamp (2011) used these aspects to estimate the potential export value of each product-country combination. The potential export value is an estimation of the export potential of a particular product-country opportunity. It was used simply to rank the export opportunities, thereby identifying the most lucrative ones; it is not a specific objective to be pursued.

\subsubsection{Final ranking of low-carbon environmental goods according to Criteria 1, 2 and 3}

Each of the three criteria discussed above assigned a score out of 5 to each low-carbon environmental good. To ensure a more normal distribution of scores, the methodology of the International Trade Centre (ITC, 2012) was used to calculate the scores for Criteria 2 and 3 , as follows:

$$
\text { score }_{\text {crit } 2 / 3}=\left\{\begin{array}{c}
5 \text { if } x \geq a \\
0 \text { if } x \leq b \\
{\left[\left(\frac{x-b}{a-b}\right) \times 5\right] \text { if } a<x<b}
\end{array}\right.
$$

where score $_{\text {crit } 2 / 3}$ is the score out of 5 allocated to the specific product in Criterion 2 or 3 ;

$x$ is the RCA of the specific product $x$ for Criterion 2 or the potential export value in Criterion 3;

$a$ is the value of the product with the second highest RCA or potential export value and represents the upper threshold;

$b$ is the value of the product with the second lowest RCA or export value and represents the lower threshold.

A score of 5 was allocated if the $x \geq a$ was true. A score of 0 was allocated if the $x \leq b$ was true. A score calculated by $\left[\left(\frac{x-b}{a-b}\right) \times 5\right]$ was allocated if $(a<x<b)$. Thus, if the RCA or potential export value of the specific product 
was not in the upper or lower threshold, a percentage of the maximum 5 points was given. This depended on where the RCA or potential export value of the specific products lay relative to the other goods. The score was rounded to the second decimal point.

To calculate the final score, the three points out of five for Criteria 1, 2 and 3 respectively were multiplied in order to favour those goods with similar scores for all three criteria.

\subsubsection{Results}

From the 39 low-carbon environmental goods identified as potentially having a positive effect on both the economy and the environment, the five goods attracting the best scores were (in descending order): photosensitive semiconductors (HS-6: 854140); towers and lattice masts (HS-6: 730820); electrical control and distribution boards less than $1 \mathrm{kV}$ (HS-6: 853710); gearing, ball screws, speed changers, torque converters (HS-6: 848340); and static converters (HS-6: 850440).

Table 2 shows the top five goods in terms of the final score, as well as their respective scores for Criteria 1, 2 and 3.

Table 2

Top five low-carbon environmental goods

\begin{tabular}{|c|l|c|c|c|c|}
\hline HS-6 & Product specification & Criterion 1 & Criterion 2 & Criterion 3 & Final score \\
\hline 854140 & Photosensitive/photovoltaic/LED semiconductors & 5 & 1.31 & 5 & 32.75 \\
\hline 730820 & Towers and lattice masts & 4 & 5 & 0.44 & 8.8 \\
\hline 853710 & Electrical control and distribution boards, <1kV & 5 & 0.45 & 2.81 & 6.32 \\
\hline 848340 & Gearing and screws & 4 & 0.72 & 1.62 & 4.67 \\
\hline 850440 & Static converters & 3 & 0.3 & 4.6 & 4.14 \\
\hline
\end{tabular}

\subsection{Identifying the intensive and} extensive export opportunities for the best low-carbon environmental goods

The process of establishing which products could, in the face of increased exports, contribute to more responsible or 'green' growth in South Africa would be incomplete if actual foreign market potential was not addressed. The Decision Support Model (DSM) has been used for this purpose.

The Decision Support Model (DSM) incorporates a screening process that facilitates export market selection through the identification of realistic export opportunities in the form of product-country combinations. The DSM uses a system of elimination, starting off with all possible world-wide product-country combinations and, through a unique filtering process, narrowing down the possibilities to those with the greatest potential in terms of market size, growth, accessibility and potential export value.

Filter 1 eliminates all countries that are high risk from a political and commercial point of view or have worrying macroeconomic indicators (Cuyvers, Steenkamp \& Viviers,
2012). Filter 2 eliminates countries whose import demand is too small or that have inadequate growth prospects (Cuyvers et al., 2012). Filter 3 eliminates countries on the basis of their perceived inaccessibility owing to, for example, the level of market concentration (measured by the Herfindahl-Hirschman index) and various barriers to entry, including transport time and cost, the quality of the country's logistics infrastructure, ad valorem equivalent tariffs and non-tariff measures (Cuyvers et al., 2012). Filter 4 then categorises the final round of potential markets according to the exporting country's current export performance in these markets in comparison with the performance of the top six competitors in each market. A potential export value is also assigned to each identified product-country combination with a view to prioritising the short-listed export opportunities.

The DSM was chosen as an appropriate methodology for identifying realistic export opportunities in this study, because, unlike most market selection tools, it investigates both existing and new export opportunities, thereby extending the scope of the export promotion effort (Cuyvers et al., 2012). 
The list of low-carbon environmental goods derived in this study was run through the DSM in order to identify viable export opportunities for these goods. The export opportunities arising out of this process were either intensive or extensive in nature.

The top 10 intensive export opportunities for the top five low-carbon environmental goods are shown in Table 3 . The first column ranks the export opportunities according to the potential export value; the second column lists the HS-6 code; the third column gives the product specification according to the UN COMTRADE (2010); the fourth column gives the export destination; and the last column gives the potential export value in thousands of US dollars (USD).

Table 3

Top 10 intensive export opportunities for top five low-carbon environmental goods

\begin{tabular}{|c|c|l|c|c|}
\hline Rank & $\begin{array}{c}\text { HS-6 } \\
\text { code }\end{array}$ & \multicolumn{1}{|c|}{ Product specification } & Export destination & $\begin{array}{c}\text { Potential export value in } \\
\text { USD (thousands) }\end{array}$ \\
\hline 1 & 854140 & Photosensitive semiconductors & Germany & 922362 \\
\hline 2 & 853710 & Electrical control and distribution boards <1kV & United States & 838671 \\
\hline 3 & 850440 & Static converters & United States & 790475 \\
\hline 4 & 854140 & Photosensitive semiconductors & Spain & 647886 \\
\hline 5 & 850440 & Static converters & China & 546884 \\
\hline 6 & 850440 & Static converters & Japan & 346731 \\
\hline 7 & 854140 & Photosensitive semiconductors & Germany & 307954 \\
\hline 8 & 850440 & Static converters & Canada & 281620 \\
\hline 9 & 853710 & Electrical control and distribution boards <1kV & 273184 \\
\hline 10 & 853710 & Electrical control and distribution boards <1kV & China & 248574 \\
\hline
\end{tabular}

Source: Steenkamp (2011)

The top 10 extensive export opportunities for the top five low-carbon environmental goods - involving the export of existing products to new markets are shown in Table 4.

\section{Table 4}

Top 10 extensive export opportunities for top five low-carbon environmental goods (existing products to new markets)

\begin{tabular}{|l|l|l|c|c|}
\hline Rank & $\begin{array}{c}\text { HS-6 } \\
\text { code }\end{array}$ & \multicolumn{1}{|c|}{ Product specification } & Export destination & $\begin{array}{c}\text { Potential export value in } \\
\text { USD (thousands) }\end{array}$ \\
\hline 1 & 854140 & Photosensitive semiconductors & China & 953255 \\
\hline 2 & 854140 & Photosensitive semiconductors & Hong Kong & 363505 \\
\hline 3 & 854140 & Photosensitive semiconductors & Czech Republic & 177443 \\
\hline 4 & 850440 & Static converters & Czech Republic & 92705 \\
\hline 5 & 850440 & Static converters & Poland & 78762 \\
\hline 6 & 854140 & Photosensitive semiconductors & Croatia & 55907 \\
\hline 7 & 853710 & Electrical control and distribution boards <1kV & Russia & 41890 \\
\hline 8 & 853710 & Electrical control and distribution boards <1kV & India & 22923 \\
\hline 9 & 848340 & Gearing and screws & Russia & 18999 \\
\hline 10 & 730820 & Towers and lattice masts & Australia & 15788 \\
\hline
\end{tabular}

4

\section{Conclusions and recommendations}

The global economy is rapidly evolving and many countries, including South Africa, are finding themselves under increasing pressure to expand their economies in a responsible manner. By adopting a 'green' growth mentality, they will be making a vital contribution to the sustainability of the planet while also creating 
new export opportunities for themselves that will help to drive their domestic economies.

With growing concerns, though, that increased export volumes are harmful to the environment, it is essential that the government and other stakeholders in South Africa apply their minds to devising a strategy that creates a much-needed momentum in the export sector but also meets environmental objectives, notably bringing about a reduction in greenhouse gas emissions. This study offered new insights into how that can be done.

The study presented an initial backdrop to the export-environment-growth conundrum by highlighting the important role played by lowcarbon environmental goods in enhancing environmentally-responsible growth through increased export activity. A complicating factor in researching low-carbon environmental goods was that there is no internationally accepted list of such goods. A key focus of this study, therefore, was deriving a single list, drawing from the lists of the World Trade Organization (WTO), the World Bank (WB), the International Centre for Trade and Sustainable Development (ICTSD) and the Fondation pour les Etudes et Recherches sur le Développement International (FERDI). A consolidated list of 39 low-carbon environmental goods was compiled, using various qualifying criteria. These goods were further evaluated in terms of their ability to decrease greenhouse gas emissions, South Africa's capacity to produce them, and the potential economic benefits to be derived from exporting the goods. A final list was then compiled showing the products that offer the best prospects for a positive effect on the South African economy and the environment as a whole.
The top five low-carbon environmental goods, ranked in terms of their assigned final score, are: photosensitive semiconductors (HS6: 854140); towers and lattice masts (HS-6: 730820); electrical control and distribution boards < 1kV (HS-6: 853710); gearing, ball screws, speed changers, torque converters (HS6: 848340); and static converters (HS-6: $850440)$.

Using the Decision Support Model (DSM), the intensive and extensive export opportunities associated with these top five lowcarbon environmental goods were identified. In this regard, the best overall intensive export opportunities according to their potential export value are: HS-6: 854140 - photosensitive semiconductors to Germany (USD 922.3 million) and HS-6: 853710 -electrical control and distribution boards smaller than $1 \mathrm{kV}$ to the United States (USD 838.6 million). The best overall extensive export opportunities, according to their potential export value, are: HS-6: 854140 - photosensitive semiconductors to China (USD 953.2 million) and HS-6: 854140 - photosensitive semiconductors to Hong Kong (USD 363.5 million).

While the study focused on the economic and export potential of the low-carbon environmental goods that South Africa already produces, there is scope for more research to be done into potential new areas of production, given the right circumstances and incentives. The production-linked effects of low-carbon environmental goods also represent a rich opportunity for more in-depth research. In the meantime, the results of this study should help to channel thinking by both the South African government and the private sector when it comes to export expansion and promotion.

\section{Endnote}

$1 R C A_{i, R S A}=\frac{X_{i, R S A} / X_{R S A}}{X_{i T} / X_{T}}$ Where, the $i$ is the specific product, $X_{R S A}$ shows total exports of South Africa and, $X_{T}$ shows total world exports. The RCA therefore shows the ratio between the percentage the exports of a specific product in South Africa and the percentage the exports of that product to all exports in the world.

\section{References}

ABOR, J. 2010. Do export status and export intensity increase firm performance? Thunderbird International Business Review, 53(1):9-18.

AITKEN, B., HANSON, G. \& HARRISON, A. 1997. Spillovers, foreign investments and export management. Workingham, UK: Addison-Wesley. 
BALINEAU, G. \& DE MELO, J. 2011. Stalemate at the negotiations on environmental goods and services at the Doha Round. Foundation for Education and Research on International Development. (Working paper, no. 28). Available at: $<\mathrm{http}: / / \mathrm{www}$. ferdi.fr/uploads/sfCmsContent/html/112/ P28.pdf $>$ [accessed 2012-02-10].

COMMITTEE ON TRADE AND ENVIRONMENT. Special Session (CTESS). 2007. Continued work under Paragraph 31 (III) of the Doha Ministerial Declaration. Job 07/(54). (Non-Paper by Canada, the European Communities, Japan, Korea, New Zealand, Norway, the Separate Customs Territory of Taiwan, Penghu, Kinmen and Matsu, Switzerland, and the United States of America). Available at: <http://www.mfat.govt.nz/ downloads/NZ-WTO/wto-doha-ministerialdeclaration27apr07.pdf $>$ [accessed 2013-10-28].

CUYVERS, L., STEENKAMP, E. \& VIVIERS, W. 2012. The methodology of the decision support model (DSM). In Cuyvers, L. \& Viviers, W. (eds.) Export promotion: A decision support model approach. Stellenbosch: Sun Press, 53-77.

CZECH, B. 2000. Shovelling fuel for a runaway train: Errant economists, shameful spenders and a plan to stop them all. Berkeley, Calif.: University of California Press.

DAVIDSON, O., WINKLER, H., KENNY, A., PRASAD, G., NKOMO, J., SPARKS, D., HOWELLS, M. \& ALFSTAD, T. 2006. Energy policies for sustainable development in South Africa: Options for the future. Cape Town: Energy Research Centre, University of Cape Town.

DU PLESSIS, S. \& SMIT, B. 2007. South Africa's growth revival after 1994. Journal of African Economies, 16(5):668-704

GROIZARD, J.L. 2007. Technology trade. University of the Balearic Islands. Available at: $<$ http://www.uib. es/depart/deaweb/webpersonal/jlgroizard/archivos/technology.pdf $>$ [accessed 2012-09-15].

HUBERTY, M. \& ZACHMANN, G. 2011. Green exports and the global product space: Prospects for EU Industrial Policy. Brussels: Bruegel Leibowitch. (Bruegel Working Paper 2011/07.)

INTERNATIONAL ENERGY AGENCY (IEA). 2008. Energy technology perspectives 2008 - scenarios and strategies to 2050 .

INTERNATIONAL TRADE CENTRE (ITC). 2011. Trade statistics for international business development. Available at: <http://www.trademap.org/> [accessed 2011-10-10].

INTERNATIONAL TRADE CENTRE (ITC). 2012. Training programme on export marketing for the South African Department of Agriculture, Forestry and Fisheries. March 2012. (Unpublished)

JONSSON, G. \& SUBRAMANIAN, A. 2001. Dynamic gains from trade: Evidence from South Africa. IMF Staff Papers, 48(1):197-224.

LABORDE, D. \& LAKATOS, C. 2012. Market access opportunities for ACP countries in environmental goods. Genève: International Centre for Trade and Sustainable Development. (ICTSD Programme on Trade and Environment, Issue paper no.17.)

LÖSCHEL, A. 2002. Technological change in economic models of environmental policies: A survey. Ecological Economics, 43:105-126.

LOW, L.P. 2011. Green growth implications for development planning. Climate \& Development Knowledge Network.

MMIEH, F., OWUSU-FRIMPONG, N. \& MORDI, C. 2012. Evaluating the contribution of the export sector to real GDP growth rate under structural adjustment programme (SAP): the case of Ghana. Thunderbird International Business Review, 54(4):493-507.

MOHR, P. \& FOURIE, L. (eds.) 2008. Economics for South African students. (4 ${ }^{\text {th }}$ ed.) Pretoria: Van Schaik. MUNDIAL, B. 2008. Global economic prospects, technology diffusion in the developing world. Washington, D.C.: World Bank.

NATIONAL PLANNING COMMISSION. 2011. National development plan: Vision for 2030. Pretoria. NAUDÉ, W., BOSKER, M. \& MATTHEE, M. 2010. Export specialisation and local economic growth. World Economy, 33(4):552-572.

PANITCHPAKDI, S. 2011. Foreword: Road to Rio +20. United Nations Conference on Trade and Development. New York: United Nations.

REIS, J.G. \& FAROLE, T. 2012. Trade competitiveness diagnostic toolkit. Washington, D.C.: World Bank. SOLARPOWERNOTES. n.d. Low-carbon technology. Available at: <http://www.solarpowernotes.com/ renewable-energy/low-carbon-technology.html> [accessed 2012-09-01]. 
STEENBLIK, R. 2005. Opening markets for environmental goods and services. Paris: Organisation for Economic Co-operation and Development.

STEENKAMP, E.A. 2011. The identification of export opportunities for South African products with special reference to Africa. Potchefstroom: North-West University, Potchefstroom Campus. (Thesis - PhD.)

TAMIOTTI, L., THE, R., KULAÇOĞLU, V., OLHOFF, A., SIMMONS, B. \& ABAZA, H. 2009. Trade and climate change. Genève: World Trade Organization. (A report by the United Nations Environmental Program and the World Trade Organization.)

TIETENBERG, T. \& LEWIS, L. 2009. Environmental and natural resource economics. ( $8^{\text {th }}$ ed.) Boston, Mass: Pearson.

UNITED NATIONS COMMODITY TRADE (UN COMTRADE). 2010. United Nations Commodity Trade statistics database. Available at: <http://comtrade.un.org/db/ce/ceDefault.aspx $>$ [accessed 2012-01-16].

VIVIERS, W., CUYVERS, L., MATTHEE, M., STEENKAMP, E., GRATER, S. \& KRUGELL, W.F. 2013. Identifying new product and service export opportunities for South Africa: Using a Decision Support Model. Paper delivered at UNCTAD Virtual Institute's international trade seminar. Genève, Switzerland. 10 October 2013.

WORLD METEOROLOGICAL ORGANIZATION (WMO). s.a. Causes of climate change. Available at: $<$ http://www. wmo.int/pages/themes/climate/causes_of_climate_change.php> [accessed 2012-01-25].

WOODERS, P. 2009. Greenhouse gas emission impacts of liberalising trade in environmental goods. Winnipeg, Man: International Institute for Sustainable Development. 